\title{
Osmotic dehydration of sweet potato (Ipomoea batatas) in ternary solutions
}

\author{
Desidratação osmótica de batata-doce (Ipomoea batatas) em soluções ternárias
}

\author{
Graziella Colato ANTONIO ${ }^{1 *}$, Patrícia Moreira AZOUBEL ${ }^{2}$, Fernanda Elizabeth Xidieh MURR², Kil Jin PARK ${ }^{1}$
}

\begin{abstract}
The aim of this work was to evaluate the osmotic dehydration of sweet potato (Ipomoea batatas) using hypertonic sucrose solutions, with or without $\mathrm{NaCl}$, at three different concentrations, at $40^{\circ} \mathrm{C}$. Highest water losses were obtained when the mixture of sucrose and $\mathrm{NaCl}$ was used. The addition of $\mathrm{NaCl}$ to osmotic solutions increases the driving force of the process and it is verified that the osmotic dehydration process is mainly influenced by changes in $\mathrm{NaCl}$ concentration, but the positive effect of the salt-sucrose interaction on soluble solids also determined the decrease of solid gain when solutes were at maximum concentrations. Mass transfer kinetics were modeled according to Peleg, Fick and Page's equations, which presented good fittings of the experimental data. Peleg's equation and Page's model presented the best fitting and showed excellent predictive capacity for water loss and salt gain data. The effective diffusivity determined using Fick's Second Law applied to slice geometry was found to be in the range from $3.82 \times 10^{-11}$ to $7.46 \times 10^{-11} \mathrm{~m}^{2} / \mathrm{s}$ for water loss and from $1.18 \times 10^{-10}$ to $3.38 \times 10^{-11} \mathrm{~m}^{2} / \mathrm{s}$ for solid gain.
\end{abstract}

Keywords: sucrose; salt; effective diffusivity; empirical models.

\section{Resumo}

O objetivo deste trabalho foi avaliar a desidratação osmótica da batata-doce (Ipomoea batatas) utilizando soluções hipertônicas de sacarose e/ou $\mathrm{NaCl}$, em três concentrações diferentes a $40^{\circ} \mathrm{C}$. As perdas de água mais elevadas foram obtidas quando se utilizou a mistura de sacarose e $\mathrm{NaCl}$. A adição do $\mathrm{NaCl}$ às soluções osmóticas aumenta a força motriz do processo. Verifica-se que o processo de desidratação osmótica é principalmente influenciado pela mudança da concentração de $\mathrm{NaCl}$, mas o efeito positivo da interação do sal com a sacarose também determinou a diminuição do ganho de sólidos quando os solutos estavam em concentrações máximas. As cinéticas de transferência de massa foram modeladas de acordo com as Equações de Peleg, de Fick e de Page, e apresentaram bons ajustes aos dados experimentais. A Equação de Peleg e o modelo da Page apresentaram os melhores ajustes e mostraram uma excelente capacidade de predição para dados de ganho de sólidos e de perda de água. A difusividade efetiva foi determinada utilizando-se a Segunda Lei de Fick aplicada à geometria de placa plana, encontrando valores de $3,82 \times 10^{-11}$ a $7,46 \times 10^{-11} \mathrm{~m}^{2} / \mathrm{s}$ para a perda de água, e de $1,18 \times 10^{-10}$ a $3,38 \times 10^{-11} \mathrm{~m}^{2} / \mathrm{s}$ para o ganho de sólidos.

Palavras-chave: sacarose; sal; difusividade efetiva; modelos empíricos.

\section{Introduction}

Sweet potato is one of the five most important food crops in developing countries. It is one of the most efficient food crops in terms of caloric value per cultivated area, being relatively easy to grow even on poor and dry soil.

The dry matter production potential of certain varieties of sweet potato may be as high as 4.3 to 6.0 tons per ha. Sweet potato is remarkable because of its high yield, palatability and crude protein content. Sweet potato, which is one of the most important tubers, is widely distributed in tropical areas. It plays a basic role in the diet of the people from tropical countries. Tropical tubers are either home or industrially processed at various scales. Nowadays, industrial processes must be improved, in order to enhance tuber uses and satisfy consumption requirements.

Osmotic dehydration is a method applied for water removal of fresh foods, by immersing pieces of the food in a solution of higher osmotic pressure, and hence of lower water activity than the food. This solution is sometimes referred to as a hypertonic solution in the literature. Water passes from the food into the solution under the influence of the osmotic pressure gradient. In this process, the walls of the cells in the food act as semi permeable membranes. However, the membranes are not completely selective. Some soluble natural substances, such as organic acids, sugars, salts, and vitamins, may be lost with the water, while solutes from the solution may penetrate into the food. This gain of solutes by the food can contribute to the reduction of its water activity, but may affect the taste of the product (LENART; FLINK, 1984; KAYMAK-ERTEKIN; SULTANOGLU, 2000; BRENNAN, 2003; EREN; KAYMAK-ERTEKIN, 2007).

In osmotic dehydration, the rate of water loss is initially high, but significantly decreases after 60 to 120 minutes. However, it can take days for the process to reach equilibrium. A typical processing time to reduce the weight of the food by $50 \%$ is from 4 to 6 hours. Some researchers have reported that,

Recebido para publicação em 19/7/2007

Aceito para publicação em 14/12/2007 (002693)

${ }^{1}$ Faculdade de Engenharia Agrícola - FEAGRI, Universidade Estadual de Campinas - UNICAMP, CP 6011, CEP 13083-875, Campinas - SP, Brasil,

E-mail: graziella.colato@agr.unicamp.br

2 Embrapa Semi-Árido, CEP 56302-970, Petrolina-PE, Brasil

${ }^{3}$ Faculdade de Engenharia de Alimentos - FEA, Departamento de Engenharia de Alimentos, Universidade Estadual de Campinas - UNICAMP, CEP 13083-97, Campinas, SP, Brasil

${ }^{*}$ A quem a correspondência deve ser enviada 
while water loss decreases rapidly in the first 2 hours, the gain of solutes from the hypertonic solution continues for a longer period of time. The initial concentration of solutes in the solution can affect the rate of water loss. Sugar concentrations in the range of 40 to $70 \%$ are used. Sometimes, a higher concentration may be achieved by solid gain, which can affect the taste of the product by making it too sweet. In the case of vegetables, sodium chloride concentrations in the range of 5 to $20 \%$ have been used. Again, at high concentrations, the taste of the product may be adversely affected (BRENNAN, 2003).

Solute choice and concentration depend on several factors, namely the effect on organoleptic quality properties, solute solubility and cell membrane permeability, which establish effect and cost. The two most common kinds of solutes in osmotic treatments are sugars (mainly with fruits) and salts (with vegetables, meat and cheese), with a predominance of the use of sucrose and sodium chloride, which show advantages already described by several authors (LENART; FLINK, 1984; COLLIGNAN; RAOULT-WACK, 1994; SACCHETTI; GIANOTTI; DALLA ROSA, 2001).

The objectives of this work were to study the osmotic dehydration of sweet potato and examine the predictive capacity of Peleg, Fick and Page's equations.

\subsection{Theory}

Peleg (1988) proposed an equation to describe sorption curves that approach equilibrium asymptotically. This equation was redefined in terms of soluble solids and moisture content. Park et al. (2002) rewrote the same Equation 1 as:

$$
\overline{M C(t)}=M C_{0} \pm \frac{t}{k_{1}+k_{2}}
$$

in which $\overline{M C(t)}$ is the amount of water or solids at time $\mathrm{t}, \mathrm{g} ; M C_{\mathrm{o}}$ is the initial amount of water or solids, g; $k_{1}$ and $k_{2}$ are Peleg's constants; and $t$ is the time, h.

A plate of thickness $2 L$ with uniform initial amount of water or solids $M C_{o}$, submied to osmotic dehydration at constant conditions, can be described by Fick's unidirectional diffusion Equation 2 (CRANK, 1975):

$$
\frac{\partial M C(t)}{\partial t}=\frac{\partial}{\partial z}\left(D_{e f} \frac{\partial M C(t)}{\partial z}\right)
$$

Using the following initial and boundary conditions:

- Uniform initial amount $\mathrm{MC}(\mathrm{z}, 0)=M C_{0}$;

- Symmetry of concentration $\left.\frac{\partial M C(t)}{\partial z}\right|_{z=0}=0$; and

- Equilibrium content at surface $M C(\mathrm{~L}, \mathrm{t})=M C_{e q}$.

And applying (Equation 3):

$\overline{M C(t)}=\frac{1}{L} \int_{0}^{L} M C(z, t) d z$

It becomes, in one dimension (CRANCK, 1975) (Equation 4):
$\overline{M C(t)}=\left(\frac{8}{\pi^{2}} \sum_{i=0}^{\infty} \frac{1}{(2 i+1)^{2}} \times \exp \left(-(2 i+1)^{2} \pi^{2} D_{e f, W \text { or } S} \frac{t}{4 L^{2}}\right)\right)$

in which $D_{\text {ef; w or S }}$ is the effective diffusivity of water loss or solid gain, $\mathrm{m}^{2} / \mathrm{s} ; i$ is the number of series terms; $L$ is the characteristic length, sample half-thickness, $\mathrm{m}$; $t$ is the time, seconds.

The calculation of effective diffusivity for solid gain and water loss can be based on the dimensionless amount of water loss $\left(W_{W}\right)$ and solid gain $\left(W_{S}\right)$ (Equation 5):

$W_{\text {Wor } S}=\frac{\overline{M C(t)}-M C_{e q}}{M C_{0}-M C_{e q}}$

in which $W_{W}$ is the dimensionless amount of water loss; $W_{S}$ is the dimensionless amount of solid gain; $M C_{e q}$ is the equilibrium amount of water loss or solid gain, $g$.

One of the most useful empirical models is Page's Equation 6 (PAGE, 1949):

$W_{W_{o r S}}=\frac{\overline{M C(t)}-M C_{e q}}{M C_{0}-M C_{e q}}=\exp \left(-A t^{B}\right)$

in which, $A$ and $B$ are Page's water loss or solid gain parameters; and $t$ is the time, s.

\section{Materials and methods}

\subsection{Preparation of sweet potato slice samples}

The raw material used was sweet potato from the Mona Lisa variety acquired at a local market. Samples were hand peeled and cut into slices $0.5 \mathrm{~mm}$ thick. Sliced sweet potatoes were immersed in osmotic solutions. Commercial sucrose and salt were used as osmotic agents.

\subsection{Osmotic dehydration}

The sweet potato slices were osmotically dehydrated. The osmotic process was carried out at different $\mathrm{NaCl}$ concentrations $(0,5$ and $10 \% \mathrm{w} / \mathrm{w})$ and fixed sucrose concentration $(50 \% \mathrm{w} / \mathrm{w})$, solution temperature $\left(40{ }^{\circ} \mathrm{C}\right)$ and agitation $(90 \mathrm{rpm})$. The slices were placed in $250 \mathrm{~mL}$ beakers containing the osmotic solution and maintained in a bath with temperature control (Tecnal, TE 421). The mass ratio of the osmotic medium to the sample was 10:1, to avoid significant dilution of the medium and subsequent decrease of the driving force during the process. Samples were removed from the solution at 15, 30, 45, 60, 75, $90,120,150,180$ and 240 minutes after immersion, drained, and the excess of solution on the surface was removed with absorbent paper.

Water Loss (WL) was expressed as the net water loss from the fresh sweet potato sample after osmotic dehydration, based on initial sample mass; Solid Gain (SG) was defined as the net 
uptake of solids by the sweet potato sample based on initial sample weight, according to the following Equations 7 and 8:

$W L=\frac{\left(w_{i} X_{i}-w_{f} X_{f}\right)}{w_{i}}$

$S G=\frac{\left(w_{f}\left(1-\frac{X_{f}}{100}\right)-w_{i}\left(1-\frac{X_{i}}{100}\right)\right)}{w_{i}}$

where $w_{i}$ and $w_{f}$ are the initial and final (time $t$ ) sample weights, respectively, $(\mathrm{g}) ; X_{i}$ and $X_{f}$ are the initial and final (time $t$ ) sample moisture contents, respectively.

The average moisture and dry matter content of the samples were determined by drying at $70{ }^{\circ} \mathrm{C}$ for 24 hours in an oven (AOAC, 1984). All the experiments were carried out in triplicate and the average value was used for calculations.

The criteria for characterizing the fitting to the model were the multiple determination coefficients $\left(R^{2}\right)$ and the mean relative deviations (E) (Equation 9):

$$
E(\%)=\frac{1}{n_{e}} \sum_{i=1}^{n_{e}}\left\|\frac{V_{E}-V_{P}}{V_{E}}\right\| 100
$$

in which $E$ is the mean relative deviation, $\mathrm{n}_{\mathrm{e}}$ is the number of experimental data, $V_{E}$ is the experimental value (water loss or solid gain) and $V_{P}$ is the calculated value (water loss or solid gain).

\section{Results and discussion}

The sweet potato osmotic dehydration experiments were carried out under different salt concentrations $(0,5,10 \% \mathrm{w} / \mathrm{w})$, sucrose concentration of $50 \% \mathrm{w} / \mathrm{w}$ and temperature of $40{ }^{\circ} \mathrm{C}$. The osmotic process was studied in terms of water loss and solid gain and is shown in Figure 1.

Water loss and solid gain of sweet potato slices increased with time. A high initial rate of water removal and solid gain, followed by a slower removal (and gain) in the later stages was observed. Several research groups have published similar curves for osmotic dehydration of foods (COLLIGNAN; RAOULT-WACK, 1994; KAYMAK-ERTEKIN; SULTANOGLU, 2000; PARK et al., 2002).

Results showed that the more concentrated dehydration solution produced the highest water loss. Highest water losses were obtained when a mixture of sucrose- $\mathrm{NaCl}$ was used as the osmotic solution, due to an apparent synergistic effect of the solutes. It was observed that adding $\mathrm{NaCl}$ to the solution resulted in an increase of the osmotic pressure gradients and, hence, higher water loss values throughout the osmosis period. Sodium chloride increases the driving force for dehydration, lowering water activity and allowing a higher rate of penetration in the material due to its low molecular weight (ISLAM; FLINK, 1982; LENART; FLINK, 1984). However, its use is limited since a salty taste is imparted to the food.
It is noted that the WL levels with $50 \%$ sucrose $/ 5 \% \mathrm{NaCl}$ are not much lower than with $50 \%$ sucrose $10 \% \mathrm{NaCl}$. This behavior permits assessing that there is an antagonistic effect of the two solutes on water loss, i.e., the use of the salt as osmotic agent increases $W L$ at certain levels of concentration. These results are in agreement with those obtained by Lenart and Flink (1984), Collignan and Raoult-Wack (1994) and Sacchetti, Gianotti and Dalla Rosa (2001). The salt-sucrose antagonistic effect on water loss is of particular interest if we consider that the chemical potential of the ternary solution increases when the concentration of both solutes increases. These results could be explained by a reduction of plasmatic membrane permeability that takes place during the plasmolysis process. Furthermore, it would be considered that, due to the different molecular dimensions, sucrose remains mainly in the extracellular space while sodium chloride can penetrate into the cell, thus leading to a reduction of the osmotic pressure gradient (SACCHETTI; GIANOTTI; DALLA ROSA, 2001).

The higher concentration of salt in the dehydration solution produces the lower solid gain. A solid gain from 1.5 to $1.6 \mathrm{~g}$ and 1.6 to $1.7 \mathrm{~g}$ is obtained after 2 hours of dehydration at $50 \%$ sucrose/ $10 \% \mathrm{NaCl}$ and $50 \%$ sucrose $/ 5 \% \mathrm{NaCl}$ solution concentrations, respectively.

In all osmotic solutions tested, $W L$ and $S G$ increased with increasing concentrations of salt. In a solution concentration of $50 \%$ sucrose $/ 10 \% \mathrm{NaCl}$, the $S G$ is lower than in a solution concentration of $50 \%$ sucrose $/ 5 \% \mathrm{NaCl}$, due to a boundary phase formed on the product surface at higher solution concentrations, decreasing the driving force between the solution and the product. Similar results were observed by Kaymak-Ertekin and Sultanoglu (2000), Sacchetti, Gianotti and Dalla Rosa (2001) and Eren and Kaymak-Ertekin (2007), working with ternary solutions.

It was expected that the results would be influenced mainly by the change in $\mathrm{NaCl}$ concentration, but the positive effect of the salt-sucrose interaction on soluble solids determined a decrease of the solid gain at maximum $\mathrm{NaCl}$ and sucrose concentrations $(50 \%$ sucrose $/ 10 \% \mathrm{NaCl})$. This effect is generally attributed to the influence of natural tissue membranes, as well as to the diffusive properties of water and solutes as a function of their respective molar masses. An increase of the osmotic pressure gradient determines a loss of functionality of the cell plasmatic membrane that allows solute entrance by the loss of its selectivity. At low salt (and high sucrose) concentrations, it is possible that the increase in permeability causes greater sucrose penetration into the samples. However, as long as the salt concentration increases (and the sucrose concentration, consequently, decreases), the competition between these solute flows increases and, due to the low molecular weight of $\mathrm{NaCl}$, this salt penetrates much more easily than sucrose, leading to a reduction in SG. This behavior can also be explained by the formation of a solid barrier at the sample surface, which can make solid mass transfer more difficult at high concentrations. This phenomenon was also observed by Lenart and Flink (1984), Heng, Guilbert and Cuq (1990) and, Baroni and Hubinger (2007).

The best results were obtained by Azuara, Garcia and Beristain (1996), using solutions containing sucrose and $\mathrm{NaCl}$ 

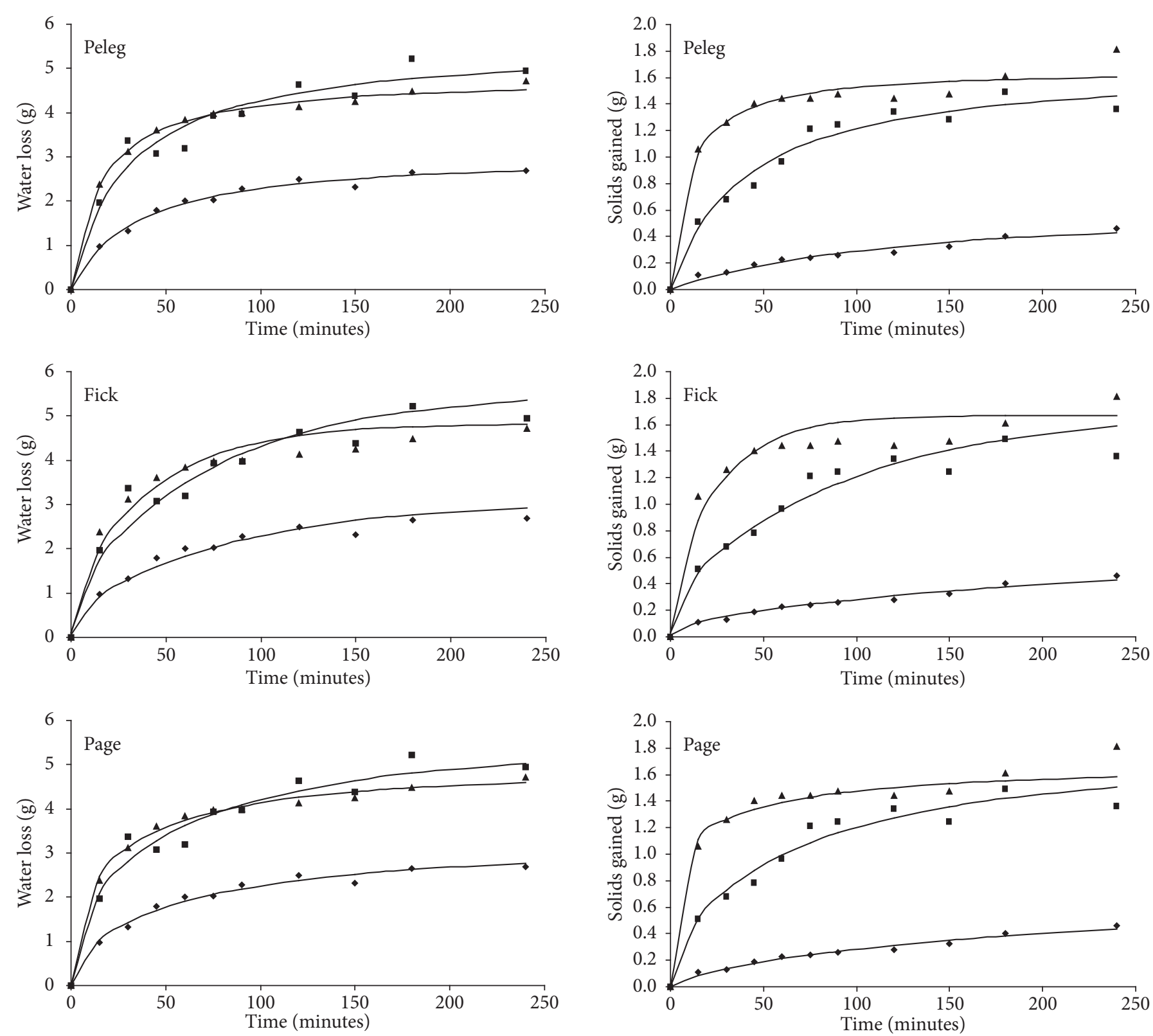

$$
\begin{array}{ll}
\text { - } \mathrm{NaCl}(0 \%)-\exp & -\mathrm{NaCl}(0 \%)-\mathrm{cal} \quad \Delta \quad \mathrm{NaCl}(5 \%) \text { - exp } \\
\text { - } \mathrm{NaCl}(10 \%)-\exp -\mathrm{NaCl}(10 \%)-\mathrm{cal} \quad \mathrm{NaCl}(5 \%) \text { - cal }
\end{array}
$$

Figure 1. Sweet potato water loss and solid gain versus time modeled according to Peleg, Fick and Page's equations.

with cylindrical slices of potato, given the fact that lower concentrations of the mixed solutes extracted as much water as highly concentrated sucrose solutions. Similar results were reported by other authors (ISLAM; FLINK, 1982; LENART; FLINK, 1984).

Peleg, Fick and Page's equations were used to fit the experimental data. In all cases, the correlation coefficient was higher than 0.95 , indicating the adequacy of the predicting model.

Peleg's equation parameters $\left(1 / k_{1}\right.$ and $\left.1 / k_{2}\right)$ for water loss and solid gain were obtained using non-linear regression analysis from the statistical package Statistica 5.0 (STATISTICA, 1995). The results are shown in Table 1 . The parameter $1 / \mathrm{k}_{1}$ describes the initial rate of mass exchange. An inverse relationship between $1 / k_{1}$ and solution concentration can be observed for water loss. From the observations made, the lowest value for $1 / \mathrm{k}_{1}$ was obtained for samples dehydrated at lower concentrations. For solid gain, the initial rate of solids $\left(1 / \mathrm{k}_{1}\right)$ presented a maximum value for intermediate levels of $\mathrm{NaCl}$ concentration.

The parameter $1 / \mathrm{k}_{2}$ describes the value of the equilibrium amount of water loss or solid gain. A relationship 
between $1 / \mathrm{k}_{2}$ and solution concentration can be observed, i.e., an increase in osmotic concentration caused an increase in the value of $1 / \mathrm{k}_{2}$ for water loss and solids. Park et al. (2002) did not find any relationship between Peleg's equation parameters and the increase of sucrose concentration at the same temperature, during osmotic dehydration of pear. The average calculated relative error ranged from 1.82 to $7.18 \%$ for water loss and from 3.89 to $10.09 \%$ for solid gain.

The values of the effective diffusion coefficients obtained for the different osmotic solution concentration combinations, calculated using Fick's model, are presented in Table 2.

The average calculated relative error varied from 9.74 to $13.93 \%$ for water loss and from 5.08 to $15.59 \%$ for solid gain. Concerning effective diffusivity, it can be observed that experimental values showed orders of magnitude between $10^{-10}$ and $10^{-11}$. Similar results were observed by Telis, Murari and Yamashita (2004), working with tomatoes in ternary solutions (sucrose and $\mathrm{NaCl}$ ). Kaymak-Ertekin and Sultanoglu (2000) found values ranging from $3.32 \times 10^{-11}$ to $21.33 \times 10^{-11} \mathrm{~m}^{2} / \mathrm{s}$ for water loss and from $3.62 \times 10^{-11}$ to $10.82 \times 10^{-11} \mathrm{~m}^{2} / \mathrm{s}$ for solute diffusivity of apples at different temperatures $\left(20-50^{\circ} \mathrm{C}\right)$ and different concentrations of sucrose and dextrose.

Page's equation parameters obtained for water loss and solid gain are shown in Table 3. The average calculated relative error varied from 5.94 to $11.47 \%$ for water loss and 5.39 to $13.09 \%$ for solid gain. The equation paramweters do not exhibit a trend either with the increase of solution concentration at the same temperature or with the increase of temperature at a constant solution concentration. Similar conclusions were made by Park et al. (2002).

The lowest average relative error was obtained using Peleg's equation. The experimental and calculated results for water loss and solid gain are shown in Figure 1.

\section{Conclusions}

The rate of water loss during osmotic dehydration of sweet potato was directly related to solution concentration. An antagonistic effect between the two solutes (sucrose and $\mathrm{NaCl}$ ) was observed where the positive salt-sucrose interaction effect on soluble solids determined a decrease of solid gain when $\mathrm{NaCl}$ and sucrose were at maximum concentrations ( $50 \%$ sucrose $/ 10 \% \mathrm{NaCl}$ ).

The experimental values of water loss and solid gain during the osmotic dehydration of sweet potato slices were fitted to Peleg, Fick and Page's equations. Peleg's equation presented the best adjustment of the experimental data.

Peleg's parameters $1 / \mathrm{k}_{1}$ and $1 / \mathrm{k}_{2}$ for water loss were from 0.09 to 0.30 and from 3.13 to 5.56, respectively, and for solid gain they varied from 0.01 to 0.18 and 0.67 to 1.67 , respectively. Page's parameters A and B for water loss were from 0.07 to 0.17 and from 0.53 to 0.62 , respectively, and for solid gain they ranged from 0.02 to 0.41 and 0.36 to 0.73 , respectively.

The effective diffusion coefficients obtained from Fick's equation ranged from $3.82 \times 10^{-10}$ to $7.46 \times 10^{-10} \mathrm{~m}^{2} / \mathrm{s}$ for water loss and from $1.18 \times 10^{-9}$ to $3.38 \times 10^{-10} \mathrm{~m}^{2} / \mathrm{s}$ for solid gain.

\section{Acknowledgments}

The authors wish to acknowledge Fundação de Amparo à Pesquisa do Estado de São Paulo (FAPESP), Conselho Nacional de Desenvolvimento Científico e Tecnológico (CNPq) and Fundação de Coordenação e Aperfeiçoamento de Pessoal de Nível Superior (CAPES).

\section{References}

AOAC - ASSOCIATION OF OFFICIAL ANALYTICAL CHEMISTS

Official Methods of Analysis. 14 ed. Arlington, 1984.

Table 1. Values of Peleg's equation parameters for water loss and solid gain.

\begin{tabular}{|c|c|c|c|c|c|c|c|c|c|c|}
\hline \multirow[t]{2}{*}{$\mathrm{T}\left({ }^{\circ} \mathrm{C}\right)$} & \multirow{2}{*}{$\begin{array}{l}\text { Sucrose } \\
(\% \mathrm{w} / \mathrm{w})\end{array}$} & \multirow{2}{*}{$\begin{array}{c}\mathrm{NaCl} \\
(\% \mathrm{w} / \mathrm{w})\end{array}$} & \multicolumn{4}{|c|}{ Water loss } & \multicolumn{4}{|c|}{ Solid gain } \\
\hline & & & $1 / \mathrm{k}_{1}$ & $1 / \mathrm{k}_{2}$ & $\mathrm{R}^{2}$ & E (\%) & $1 / \mathrm{k}_{1}$ & $1 / \mathrm{k}_{2}$ & $\mathrm{R}^{2}$ & E (\%) \\
\hline \multirow[t]{3}{*}{40} & 50 & 0 & 0.09 & 3.13 & 0.99 & 3.92 & 0.01 & 0.67 & 0.98 & 10.09 \\
\hline & & 5 & 0.19 & 4.76 & 0.99 & 1.82 & 0.18 & 1.67 & 0.98 & 3.89 \\
\hline & & 10 & 0.30 & 5.56 & 0.98 & 7.18 & 0.04 & 1.72 & 0.98 & 7.58 \\
\hline
\end{tabular}

Table 2. Values of Fick's equation parameters for water loss and solid gain.

\begin{tabular}{|c|c|c|c|c|c|c|c|c|}
\hline \multirow[t]{2}{*}{$\mathrm{T}\left({ }^{\circ} \mathrm{C}\right)$} & \multirow{2}{*}{$\begin{array}{l}\text { Sucrose } \\
(\% \mathrm{w} / \mathrm{w})\end{array}$} & \multirow{2}{*}{$\begin{array}{c}\mathrm{NaCl} \\
(\% \mathrm{w} / \mathrm{w})\end{array}$} & \multicolumn{3}{|c|}{ Water loss } & \multicolumn{3}{|c|}{ Solid gain } \\
\hline & & & $\mathrm{D}_{\mathrm{ef}}\left(\mathrm{m}^{2} / \mathrm{s}\right)$ & $\mathrm{R}^{2}$ & E (\%) & $\mathrm{D}_{\mathrm{ef}}\left(\mathrm{m}^{2} / \mathrm{s}\right)$ & $\mathrm{R}^{2}$ & E (\%) \\
\hline \multirow[t]{3}{*}{40} & 50 & 0 & $3.82 \times 10^{-11}$ & 0.98 & 9.74 & $1.16 \times 10^{-11}$ & 0.99 & 5.08 \\
\hline & & 5 & $7.46 \times 10^{-11}$ & 0.98 & 11.23 & $1.18 \times 10^{-10}$ & 0.95 & 15.59 \\
\hline & & 10 & $4.28 \times 10^{-11}$ & 0.97 & 13.93 & $3.38 \times 10^{-11}$ & 0.97 & 10.71 \\
\hline
\end{tabular}

Table 3. Values of Page's equation parameters for water loss and solid gain.

\begin{tabular}{|c|c|c|c|c|c|c|c|c|c|c|}
\hline \multirow[t]{2}{*}{$\mathrm{T}\left({ }^{\circ} \mathrm{C}\right)$} & \multirow{2}{*}{$\begin{array}{l}\text { Sucrose } \\
(\% \mathrm{w} / \mathrm{w})\end{array}$} & \multirow{2}{*}{$\begin{array}{c}\mathrm{NaCl} \\
(\% \mathrm{w} / \mathrm{w})\end{array}$} & \multicolumn{4}{|c|}{ Water loss } & \multicolumn{4}{|c|}{ Solid gain } \\
\hline & & & $\mathrm{A}$ & $B$ & $\mathrm{R}^{2}$ & E (\%) & A & B & $\mathrm{R}^{2}$ & E (\%) \\
\hline \multirow[t]{3}{*}{40} & 50 & 0 & 0.07 & 0.62 & 0.99 & 9.08 & 0.02 & 0.73 & 0.99 & 5.39 \\
\hline & & 5 & 0.17 & 0.53 & 0.99 & 5.94 & 0.41 & 0.36 & 0.99 & 10.98 \\
\hline & & 10 & 0.10 & 0.58 & 0.98 & 11.47 & 0.06 & 0.65 & 0.98 & 13.09 \\
\hline
\end{tabular}


AZUARA, E.; GARCIA, H. S.; BERISTAIN, C. I. Effect of the centrifugal force on osmotic dehydration of potato and apples. Food Research International, v. 22, n. 2, p. 195-199, 1996.

BRENNAN, J. G. Dielectric and Osmotic Drying. Encyclopedia of Food Sciences and Nutrition. London: Elsevier Science, 2003. p.1938-1942.

COLLIGNAN, A.; RAOULT-WACK, A. L. Dewatering and salting of cod by immersion in concentrated sugar/sal solutions. LebensmittelWissenschaft und Technologie, v. 27, n. 3, p. 259-264, 1994.

CRANK, J. The mathematical of diffusion. 2 ed. Oxford: Claredon Press, 1975. 414p.

EREN, I.; KAYMAK-ERTEKIN, F. Optimization of osmotic dehydration of potato using response surface methodology. Journal of Food Engineering, v. 79, n. 1, p. 344-352, 2007.

HENG, K.; GUILBERT, S.; CUQ, J. L. Osmotic dehydration of papaya: influence of process variables on the product quality. Sciences des Aliments, v. 10, n. 4, p. 831-848, 1990.

ISLAM, M. N.; FLINK, L. N. Dehydration of potato II - osmotic concentration and its effect on air drying behavior. Journal of Food Technology, v. 17, p. 387-403, 1982.

KAYMAK-ERTEKIN, F.; SULTANOGLU, M. Modelling of mass transfer during osmotic dehydration of apples. Journal of Food Engineering, v. 46, n. 4, p. 243-250, 2000.

LENART, A.; FLINK, J. M. Osmotic concentration of potato. I. Criteria for the end-point of the osmosis process. Journal of Food Technology, v. 19, p. 45-63, 1984.
PAGE, G. E. Factors influencing the maximum of air drying shelled corn in thin layer. USA, 1949. Thesis - (M. Sc.), Purdue University, Indiana.

PARK, K. J.; BIN, A.; BROD, F. P. R.; PARK, T. H. K. B. Osmotic dehydration kinetics of pear D’anjou (Pyrus communis L.). Journal of Food Engineering, v. 52, n. 3, p. 293-298, 2002.

PELEG, M. An empirical model for the description of moisture sorption curves. Journal of Food Science, v. 53, n. 4, p. 1216-1219, 1988.

RAOULT-WACK, A. L.; LAFONT, F.; RIOS, G.; GUILBERT, S. Osmotic dehydration: Study of mass transfer in terms of engineering properties. In: A.S. Mujumdar and M. Roques (Ed.). Drying ' 89. New York, USA: Hemisphere Publ. Corp, 1989. p. 487-495.

SACCHETTI, G.; GIANOTTI, A.; DALLA ROSA, M. Sucrose-salt combined effects on mass transfer kinetics and product acceptability. Study on apple osmotic treatments. Journal of Food Engineering, v. 49, p. 163-173, 2001.

STATSOFT Inc. Computer program manual. STATISTICA for Windows 5.0.Tulsa: StatSoft, Inc., 1995.

TELIS, V. R. N.; MURARI, R. C. B. D. L.; YAMASHITA, F. Diffusion coefficients during osmotic dehydration of tomatoes in ternary solutions. Journal of Food Engineering, v. 61, n. 2, p. 253-259, 2004.

TONON, R. V.; BARONI, A. F.; HUBINGER, M. D. Osmotic dehydration of tomato in ternary solutions: Influence of process variables on mass transfer kinetics and an evaluation of the retention of carotenoids. Journal of Food Engineering, v. 82, p. 509-517, 2007. 